\title{
O charme sapatão de Esther Newton: uma entrevista sobre a vida, a obra e as paixões da lendária antropóloga
}

\author{
Esther Newton's Butch Charm: An Interview on the Life, Work and Passions of \\ The Legendary Anthropologist
}

Carlos Eduardo Henning' (iD) 0000-0003-2103-2821

'Universidade Federal de Goiás, Faculdade de Ciências Sociais, Programa de PósGraduação em Antropologia Social, Goiânia, GO, Brasil.

74110-110-ppgasufg@yahoo.com.br

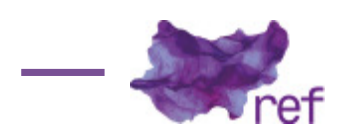

Sempre ensinei a meus estudantes, [...] que a primeira coisa que é preciso fazer é sobreviver! Eu sobrevivi. ${ }^{1}$ Esther Newton

A antropóloga estadunidense Esther Newton é uma dessas figuras fascinantes e cruciais que levaram injustamente um longo tempo para alcançar parte do devido respeito, reconhecimento e admiração que lhes são de direito ${ }^{2}$. Nascida em 1940, na cidade de Nova York, proveniente de uma família de classe média, de pais progressistas, intelectualizados e de esquerda, Newton se refere a si mesma como marcada desde cedo por fortes sentimentos de inadequação social. Em especial por não ter podido viver, por muitos anos, sua masculinidade como desejava e por ter precisado ocultar quando jovem o fato de ser uma lésbica butch ${ }^{3}$. Boa parte da sedutora odisseia de dores, glórias e realizações da autora, aliás, é narrada em seu livro de memórias My Butch Career: a memoir (2018)4, o qual pude resenhar recentemente (Carlos HENNING, 2019a, 2019b).

Como um contraponto ao clima macarthista de vigilância quase paranoica, Newton recorda na adolescência ter seu primeiro contato com a antropologia através do livro Coming of Age in Samoa de Margaret Mead (1928). Tal leitura a fez sentir uma fascinação e um enorme alívio ao acessar o debate sobre o relativismo cultural na análise do caráter arbitrário e variável das "relações entre os sexos". Apesar do contexto desafiador, ainda bastante jovem, Newton manteria contato corajosamente com o movimento homófilo em defesa dos direitos de homossexuais - no caso, a Mattachine Society ${ }^{5}$ e o grupo lésbico Daughters of Billitis ${ }^{6}$ - em fins da década de $1950^{7}$.

\footnotetext{
' Frase proferida na entrevista aqui concedida. No original: "I always taught my students, [...] that the first thing you've got to do is survive! I did."

${ }^{2}$ Agradeço a Esther Newton, Glauco B. Ferreira, Eunilda Henning, Camilo Braz, Agustin Liarte Tiloca, Andrea Lacombe e às/aos revisoras/es da REF por leituras, sugestões e contribuições para a versão final do texto aqui apresentada.

${ }^{3}$ Butch é uma identidade associada a mulheres mais masculinas que frequentavam bares lésbicos no bairro do Greenwich Village nas décadas de 1950 e 1960, em Nova York. As butches em geral se interessavam pelas femmes. Butch poderia ser traduzida ao português do Brasil como "sapatão" ou "caminhoneira".

${ }^{4}$ A tradução aproximada do título ao português brasileiro seria algo como: Minha Carreira Sapatão: um livro de memórias.

${ }^{5}$ Uma das primeiras organizações em defesa dos direitos de homossexuais - em sua vertente homófila pré-Stonewall - nos Estados Unidos, fundada em 1950 em Los Angeles. Cf. Rubin (2016).

${ }^{6}$ A Daughters of Bilitis (DOB) foi uma organização de direitos lésbicos com base em São Francisco, na Califórnia, e fundada no período inicial do ativismo homófilo, em meados da década de 1950. Cf. Rubin (2016).

${ }^{7}$ Em uma menção irônica à sua primeira influência na antropologia, Newton publicaria em 2000 um livro de ensaios intitulado Margaret Mead Made Me Gay: personal essays, public ideas, algo como Margaret Mead me Fez Gay: ensaios pessoais, ideias públicas.
} 
Tida como parte da primeira geração de intelectuais que integraram ou foram diretamente influenciados/as pelo movimento de liberação homossexual estadunidense pós-Stonewall ${ }^{8}$, Newton faz questão de frisar nesta entrevista que a maior parte de suas obras esteve diretamente enraizada nos dilemas e problemáticas dos movimentos feministas e homossexuais dos anos 1960 em diante: "É preciso sempre saber sobre quais ombros você se apoia para não ficar reinventando a roda ou ignorando quem veio antes de você", afirma a autora.

Embora seu pai, um eminente psicanalista judeu de Nova York, desejasse que a filha se tornasse psicóloga, Newton acabou estudando História na graduação realizada na Universidade de Michigan, e na pós-graduação ingressou no mundo da Antropologia, digamos, pela porta da frente. Fez seu doutorado no Departamento de Antropologia da Universidade de Chicago orientada por David Schneider, importante referência na antropologia simbólica e nos estudos de parentesco. Além de mentor, seu orientador viria a se tornar também um amigo e apoiador por toda a vida.

Inicialmente Newton pensava em fazer trabalho de campo para o doutorado em Fiji. Entretanto, ao apresentar um paper final de disciplina sobre a organização social das drag queens ou female impersonators (transformistas) na cidade de Chicago - usando métodos etnográficos tradicionalmente mobilizados em contextos não-ocidentais - Schneider a teria incentivado a alterar o seu tema de pesquisa. Em uma decisão que impactaria toda a sua carreira, Newton mudou o tema e concluiu sua tese de doutorado em 1968 sob o título The 'Drag Queens: a study in urban anthropology. Sua banca final contou - além de Schneider - com ninguém menos que Julian Pitt-Rivers e Clifford Geertz.

Tal etnografia seria publicada em livro, o hoje clássico, Mother Camp: Female Impersonators in America em 1972 (Esther NEWTON, 1979). Na obra ela analisa etnograficamente com apuro e precisão o universo das female impersonators e drag queens, nas cidades de Chicago e Kansas City na primeira metade dos anos 1960. É preciso ressaltar que estudos sobre "comunidades sexuais minoritárias" (Gayle RUBIN, 2018b) eram, então, vistos em grande medida como aberrantes e investigações sobre pessoas hoje nomeadas como LGBTI ${ }^{9}$ eram consideradas - mesmo nas ciências sociais - como algo próprio da psiquiatria ou mesmo da criminologia. Newton, portanto, foi arrojada e arriscou muito naquele período ao se associar publicamente, de algum modo, a grupos tidos como desviantes.

Realizar etnografias em contextos urbanos ocidentais, em si, era algo incomum na antropologia cultural nesse período, o que contribuía para uma deslegitimação de tais pesquisas como não sendo verdadeiramente antropológicas. Desse modo, a publicação de sua tese contribuiu até certo ponto também para uma viabilização e legitimação da antropologia urbana à época ${ }^{10}$. Acima de tudo, entretanto, Mother Camp é vista como a obra que alçou Esther Newton a pioneira e precursora do campo de estudos antropológicos sobre gênero e sexualidade, assim como do campo mais amplo de estudos LGBTIQ. Mais recentemente, aliás, esta obra tem sido reposicionada como importante antepassada dos estudos queer (RUBIN, 2018a, 2016).

É preciso frisar que ao livro Mother Camp são atribuídos insights e contribuições centrais para obras de influentes intelectuais feministas das últimas décadas. Entre elas a antropóloga Gayle Rubin (1975, 1984, 2016, 2018a, 2018b) e a filósofa pós-estruturalista Judith Butler (1990). Nesse sentido, Rubin pondera que:

Meu próprio trabalho possui uma profunda dívida com estudiosos como Esther Newton [...] [que] percebeu o modo como a inversão de gênero no fazer drag 'questiona a 'naturalidade' do sistema de papéis sexuais na sua totalidade; se o comportamento relativo a um papel sexual pode ser alcançado pelo sexo 'errado', segue-se logicamente que ele [o papel sexual] é na realidade também realizado, e não herdado, pelo sexo 'correto'” [sendo algo] superficial e que pode ser manipulado. (RUBIN, 2018b, p. 274).

Entretanto, Rubin (2018b, p. 278) também aponta que as contribuições e inovações extraordinárias trazidas por Mother Camp, muitas vezes ou são ignoradas ou são tomadas como triviais aos olhos contemporâneos. É justamente, porém, o que Newton chama nesta entrevista de "o insight da performance" presente em Mother Camp - que faria dessa obra uma das referências centrais para Judith Butler (2003 [1990])" ${ }^{11}$. A própria Butler discorre sobre as contribuições de Newton para a sua noção de performatividade de gênero:

\footnotetext{
${ }^{8}$ A Revolta de Stonewall, ocorrida em junho de 1969, pode ser vista como um conjunto de dias de conflitos respondendo à violência policial contra frequentadores/as de bares gays em Nova York. Apesar de ter se tornado um símbolo de lutas transnacionais de movimentos gays liberacionistas, assim como, posteriormente, para movimentos LGBTQI, ocorreram movimentos e organizações com propósitos análogos anteriormente nos Estados Unidos, como nos anos 1920 a Society for Human Rights de Chicago, e os já citados movimentos homófilos da Mattachine Society e Daughters of Bilitis entre os anos 1950 e 1960.

${ }^{9}$ Acrônimo para Lésbicas, Gays, Bissexuais, Travestis, Transexuais, Transgêneros, Intersexuais, Queers, entre outros sujeitos. ${ }^{10}$ Sobre a influência da Escola de Chicago, da sociologia urbana e dos estudos de comunidade para o desenvolvimento de etnografias urbanas na América do Norte, consultar: Rubin (2016, 2018b).

11 Junto, é claro, a variadas outras influências e diálogos como teorias de cunho mais filosófico sobre performance e os atos de fala.
} 
Em Mother Camp [...], a antropóloga Esther Newton sugere que a estrutura do travestimento revela um dos principais mecanismos de fabricação através dos quais se dá a construção social do gênero. [...] Ao imitar o gênero, o drag revela implicitamente a estrutura imitativa do próprio gênero - assim como sua contingência. (BUTLER, 2003 [1990], p. 195-196, grifos no original).

Embora muito influente, Mother Camp, entretanto, só o seria efetivamente a posteriori. Na época de seu lançamento foi recebido glacialmente, o que se refletiu em pouquíssimas resenhas, causou quase nenhuma reverberação e pareceu à autora estar fadado ao esquecimento ${ }^{12}$. 0 reconhecimento das contribuições dessa obra e de seu pioneirismo, de fato, não viria tão cedo. Os impactos e o amargor pela recepção do livro primogênito, assim como pela dura lida cotidiana com o machismo e a homofobia/lesbofobia sistêmicos da época, por outro lado, afloram explicitamente em vários pontos da entrevista aqui publicada.

Na segunda metade da década de 1970, após uma série de desilusões profissionais com a academia que envolveram também sua demissão do primeiro emprego como docente universitária (presumivelmente pelo fato de ser feminista e lésbica), Newton passaria a viver alguns anos em Paris em uma espécie de autoexílio. Nesse período teve contato e participou de reuniões de influentes grupos feministas franceses, como dos coletivos de Hélène Cixous, Antoinette Fouque e Monique Wittig.

Ao retornar aos Estados Unidos, no início dos anos 1980, Newton ainda faria parte da Conferência do Barnard College sobre Sexualidade Feminina, ocorrida em abril de 1982. Evento que incidiria decisivamente nas "guerras sexuais" feministas da época e resultaria na coletânea editada por Carole Vance (1984): Pleasure and Danger: exploring female sexuality (Carole VANCE, 1984). Esse evento contribuiria para uma reaproximação de Newton do universo acadêmico e marcaria também o início, finalmente, do reconhecimento público de suas contribuições pioneiras. Essas rearticulações, aliás, fariam com que autora se tornasse parte destacada da primeira seção da American Anthropological Association voltada a antropólogas e antropólogos lésbicas e gays: a SOLGA ${ }^{13}$.

Além de Mother Camp, porém, Newton ainda publicaria obras de fôlego, como o livro Womenfriends: a soap opera (1976) em coautoria com Shirley Walton, refletindo sobre dilemas do feminismo de segunda onda sobre identidades sexuais e a crítica à invisibilização das lésbicas no movimento (Esther NEWTON; Shirley WALTON, 1976). Publicaria também Cherry Grove, Fire Island: Sixty Years in America's First Gay and Lesbian Town (NEWTON, 1993), sua segunda etnografia, na qual enfoca lésbicas e gays na meia idade e na velhice que viviam ou visitavam com regularidade o primeiro balneário gay e lésbico dos Estados Unidos, próximo à cidade de Nova York. A seguir publicou o livro de ensaios Margaret Mead Made Me Gay: Personal Essays, Public Ideas (NEWTON, 2000) e, por fim, My Butch Career: a memoir (NEWTON, 2018), sua obra mais recente.

Tive a oportunidade de conhecer e conversar com Esther Newton pessoalmente em conferências de lançamento de seu livro de memórias em meados de março de 2019, enquanto eu realizava um período de pós-doutoramento na Columbia University na cidade de Nova York ${ }^{14}$. Desde nossa primeira interação Newton se mostrou muito acessível, simpática e solícita, aceitando prontamente me conceder uma entrevista, a qual se realizou semanas mais tarde, no dia 24 de maio de 2019. Nosso diálogo ocorreu pelo aplicativo FaceTime enquanto eu estava em Nova York e Newton se encontrava em Ann Arbor, no estado de Michigan.

Tendo em mente que suas obras, até onde sei, são inéditas em português, ter acesso em língua portuguesa à entrevista de Esther Newton - que completa 80 anos de idade em 2020 - é algo particularmente significativo ${ }^{15}$. Em primeiro lugar por dar acesso ao público lusófono à narrativa da

\footnotetext{
${ }^{12}$ Sobre a imediata recepção de Mother Camp, Gayle Rubin afirma que: "Embora Mother Camp devesse ter marcado uma nova onda de trabalhos sobre homossexualidade dentro da antropologia, o livro foi em grande medida ignorado e a ele se seguiu um trovejante silêncio que perdurou por um longo e doloroso hiato. Por muitos anos, Mother Camp permaneceu solitário, um documento excepcional sem companhia ou sucessores aparentes. Seriam necessárias quase duas décadas até que houvesse uma maior quantidade de literatura antropológica sobre comunidades gays urbanas nos Estados Unidos." (RUBIN, 2018b, p. 278).

${ }^{13} \mathrm{Na}$ verdade, inicialmente intitulada ARGOH - Anthropology Research Group on Homosexuality (ou Grupo de Pesquisa Antropológica sobre Homossexualidade) ainda nos anos 1970, passando em 1988 a se intitular SOLGA - The Society of Lesbian and Gay Anthropologists (Sociedade de Antropólogas/os Lésbicas e Gays). Mais recentemente seu nome foi alterado para AQA - The Association for Queer Anthropology (Associação de/para uma Antropologia Queer). Tal Associação é uma seção da American Anthropological Association voltada a promover a pesquisa e a educação antropológica sobre homossexualidade, bissexualidade, transgeneridade, transexualidade e outras identidades e expressões sexuais e de gênero, e suas intersecções com raça, classe, pessoas com deficiências, além de questões de nacionalidade, colonialismo e globalização. Mais informações cf: https://queeranthro.org.

${ }^{14} \mathrm{O}$ pós-doutorado ocorreu no Institute of Latin American Studies da Columbia University. Agradeço o apoio inestimável de Richard Parker, Gustavo S. Azenha e Esteban Andrade do ILAS, a Socrates Silva da Lehman Library, assim como a Miriam Grossi por dicas e sugestões antes de minha chegada à cidade.

${ }^{15}$ No caso brasileiro, apesar da ausência de traduções das obras de Newton um trabalho pioneiro diretamente influenciado por Mother Camp é a excelente etnografia Fervendo com as Drags: corporalidades e performances de drag queens em territórios gays da Ilha de Santa Catarina, de Anna Paula Vencato (2002). VENCATO, Anna Paula. Fervendo com as Drags: corporalidades e performances de drag queens em territórios gays da ilha de Santa Catarina. Dissertação de Mestrado em Antropologia Social, Programa de Pós-Graduação em Antropologia Social, UFSC, Florianópolis, 2002. Disponível em: https://repositorio.ufsc.br/xmlui/handle/123456789/84381. Acesso em: 02/03/2020.
} 
autora sobre sua vida, obra, carreira e paixões, bem como a um conjunto de profundos câmbios em diversos âmbitos sociais. Suas publicações e percurso biográfico descortinam transformações, por exemplo: a) na antropologia cultural norte-americana dos anos 1960 em diante; b) na academia fortemente machista, homo/lesbofóbica e racista da época; c) nos movimentos feministas a partir da segunda onda; d) nos movimentos homófilos e de liberação homossexual; e) nas maneiras como identidades sexuais e de gênero se reconfiguraram no período em questão; f) e nas condições, em si, para a recepção e reconhecimento das obras de Newton e de intelectuais de mesma geração. Espero, por fim, que todas, todos e todes possam acessar o caráter fascinante, envolvente e, por vezes, extraordinariamente franco dessa narrativa sobre o prodigioso percurso biográfico da autora.

Carlos Eduardo Henning (CEH): Muito obrigado por conceder esta entrevista. Acabei de ler suas memórias, My Butch Career. É um livro fascinante e não é apenas para acadêmicos/as. Parabéns!

Esther Newton (EN): Bem, obrigada. É assim que escrevi a maior parte do meu trabalho. Quero que seja acessível a leitoras/es que não sejam antropólogas/os. Isso porque tudo, exceto meu primeiro livro, surgiu do movimento. Eu sempre tive meu público em mente, como uma maneira de fazer avançar nossas causas. Até hoje sem a comunidade queer, eu não seria nada. Todo prêmio, toda fala pública que eu faço, algumas eram promovidas por feministas que gostavam do meu trabalho, mas não eram queer, mas na maioria das vezes são todas promovidas por pessoas queers. Não recebi um prêmio pelo conjunto da minha obra do campo da antropologia per se, sabe? Não foi da American Anthropological Association, eu recebi o prêmio de queers ${ }^{16}$. É claro que fiquei extremamente feliz com isso, pois, sem o apoio dessas pessoas, eu nunca seria reconhecida. Na verdade, escrevi minhas obras tendo os movimentos em mente como meu público mais do que a academia, porque até bem mais tarde na minha carreira a academia não era realmente muito interessante.

CEH: Entendo. Eu estava em suas conferências de lançamento do seu livro de memórias aqui em Nova York em meados de março de 2019 e me dei conta de que você já planejava escrever My Butch Career há mais de duas décadas. Por que foi tão demorado para publicá-lo?

EN: Bem, até que o e-mail surgisse, eu sempre mantive diários. Então, eu tinha muito material lá. Tudo mudou quando comecei a escrever e-mails. Acho que meu primeiro computador foi em 1984, algo assim. Até essa época eu sempre tive diários e sempre quis fazer algo com eles. Então fui convidada para fazer a Kessler Lecture, em 1996, que é uma palestra uma vez por ano no Center for Lesbian and Gay Studies ${ }^{17}$. Recebi essa honraria. Comecei a pensar na minha vida e no que poderia fazer com esse convite. A conferência foi realmente um enorme sucesso. O auditório estava lotado, fui aplaudida de pé e depois disso algumas pessoas vieram até mim e disseram que eu deveria escrever um livro de memórias. E essa foi a gênese do livro, embora outra gênese tenha sido quando morei na França ${ }^{18}$. Eu estava escrevendo um romance na época, e ele não deu certo como romance, mas parte desse material, especialmente aqueles dois capítulos em minhas memórias que se passam na França, saiu disso. Bem, o problema é que... na época em que comecei a trabalhar nas memórias, ainda estava trabalhando em período integral.

CEH: Imagino que deve ter sido difícil.

EN: Sim, com certeza. Uma carga enorme de aulas e um longo trajeto diário até o trabalho. Realmente não era possível fazer muita coisa até chegar o verão. Então, isso foi de 1996 a 2006 , ano em que me aposentei da Purchase. Depois disso, trabalhei na Universidade de Michigan. Lá consegui um vínculo do tipo professora visitante. A partir daí tive muito tempo. Na verdade, acho que estou trabalhando nisso há mais tempo, porque foram 23 anos desde 1996! Bem, eu terminei o livro em 2018, enfim... Eu ainda estava trabalhando meio período até quatro anos atrás. Depois que precisei me aposentar, tive muito mais tempo para trabalhar nele e terminá-lo, apesar dos

\footnotetext{
${ }^{16}$ Aqui Newton se refere ao Distinguished Achievement Award da Association for Queer Anthropology, parte da American Anthropological Association, recebido por ela em 2018.

17 Em 1996 Newton foi convidada a ministrar uma conferência, a prestigiosa David Kessler Lecture do Center for Lesbian and Gay Studies (CLAGS) - hoje em dia intitulado Center for LGBTQ Studies - instituição parte do Graduate Center da City University of New York (CUNY). Em 1999 Newton recebeu duas bolsas que a permitiram um período sabático. As bolsas foram concedidas respectivamente pela Rockefeller Foundation e a President's Research Support Grant do Purchase College da State University of New York.

${ }^{18}$ Esther Newton viveu por cerca de seis anos na França, em Paris, na segunda metade da década de 1970.
} 
problemas de saúde que tive nesses últimos quatro anos. Então, de certo modo, esses últimos quatro anos foram mais difíceis do que os dezoito primeiros. E houve três edições principais no livro.

CEH: Pode falar um pouco sobre isso?

EN: Sim, porque em um determinado momento eu fiquei meio empacada e pensei que o livro não estava realmente se encaixando direito. Uma vez que a Duke University Press o aceitou e eu Ihes enviei um esboço do livro, houve outro processo de edição feito por três avaliadores. E eles fizeram um ótimo trabalho. Afinal, esse é um assunto muito importante, pois é a minha vida! [Risos] E é difícil cair em si sobre a ideia de: "Não, isso é um livro! E tem que ter um enredo, uma linha condutora", sabe? Esse é um grande problema para escritoras/es queer. Talvez não tanto quanto costumava ser antigamente porque agora há mais pessoas que estão fora do armário. As reações que recebi ao meu trabalho do começo da minha carreira até a década de 1980 foi, digamos, "isso não é realmente relevante, esse assunto não é de fato um tópico legítimo", sabe? Era assim que meu trabalho era rejeitado na época! Enquanto que hoje em dia, se você tem gente interessada no seu trabalho, gente que está disposta a ajudá-la a contar sua história, em oposição ao que elas acham que deveria ser a sua história, isso ajuda muitíssimo.

CEH: Com certeza. Inicialmente o livro cobriria toda a sua vida ou apenas a primeira metade dela? Porque a edição que conhecemos cobre apenas até os seus quarenta e poucos anos, não é?

EN: Correto. Não, o livro nunca cobriria a minha vida toda. Isso pois eu não tinha diários para a segunda metade da minha vida. Eu acho que parei em 1991. Então, você sabe, o livro teria sido muito diferente. Muitas pessoas me falam: "estamos esperando a continuação!" [Risos]. Não sei se haverá uma continuação, pois já consumi tanta energia para finalizá-lo. Vamos ver, estou reorganizando minha vida desde que me aposentei.

CEH: Desde o lançamento, como você tem percebido a recepção de suas memórias?

EN: Tem sido ótima. Não tive uma única crítica negativa. Tive críticas muito positivas, inclusive na The New Yorker, o que é algo realmente importante. Algumas das resenhas foram curtas, mas ainda assim o livro quebrou a caixinha queer. Isso não acontece assim tão facilmente. Pelo menos nunca tinha acontecido comigo antes. Houve uma excelente resenha na Los Angeles Review of Books. Então essa foi provavelmente a primeira vez que experimentei algo assim. Mas deixe eu te dizer, todas essas críticas, até onde eu sei, foram feitas por pessoas queer. Sabe, havia alguém, na equipe desses jornais e revistas, que disse: "Estou interessado/a neste livro, quero resenhá-lo!" e que era gay. Ou seja, os críticos eram todos gays ou lésbicas.

CEH: Sim. Você poderia falar um pouco sobre o título de suas memórias My Butch Career? EN: O título tem a ver com o fato de que se assumir homossexual, naquela época, era totalmente impossível. Quando eu estava na faculdade, fui expulsa do meu dormitório porque fui vista dentro de uma cabine telefônica com outra mulher. E nós nem sequer éramos amantes. Na verdade eu tive sorte, pois algumas amigas minhas foram expulsas da faculdade por serem lésbicas ou suspeitas de serem lésbicas. Era quase impossível pensar propriamente em uma carreira se você fosse homossexual. "Carreira", na verdade, é um conceito de classe média e classe média alta. Você não tem uma carreira como ghost writer ou algo assim. Você sabe, existem conceitos diferentes de curso da vida em diferentes classes sociais. E eu sempre fui muito sensível e atenta à classe, isso se reflete em todos os meus livros. Pessoas da classe média e da classe média alta, se quisessem ter uma carreira - sabe, como advogada/o, professor/a, médica/o ou algo assim - naquela época era impossível conciliar. Era impossível ser homossexual assumida, e muito menos uma butch, e ter uma carreira. Butch, aliás, era conceito que na época, de fato, vinha da classe trabalhadora. Então, a ideia de uma "carreira butch" tem a ver com tudo isso.

CEH: Reler seus diários para escrever o livro, imagino, deve ter sido difícil em alguns momentos. Escrever sobre você e seus ancestrais, rever sua vida, ajudou de alguma maneira a fechar questões abertas do passado, entender melhor momentos difíceis pelos quais você passou, a curar algumas feridas?

EN: Foi bem assim, exatamente. Por um lado, acho que sendo o que chamamos de uma antropóloga histórica [a historical anthropologist], alguém que é formado em História na graduação, tenho uma mente muito voltada à história. Então parecia que meu livro de memórias precisava começar com meus pais. Porque esse foi o contexto em que cresci e fui formada. Meu pai teve 10 filhos, ele definitivamente era meu modelo de masculinidade. Era um cara muito masculino para os padrões convencionais. Ele era violento, dirigia como um louco, era assustador. Ele sempre teve muitas mulheres. Eu o amei e o idolatrei por anos. Ele realmente era meu principal modelo de masculinidade. Mais tarde, houve outras referências de filmes, como Errol Flynn. Não que eu não 
goste da feminilidade, é claro, eu só não quero ser. Mas o livro tratou de algumas questões bem difíceis. Particularmente na parte sobre a morte de meu pai. Eu era tão ambivalente em relação ao meu pai. Mesmo se ele era mesmo meu pai. Aquele capítulo escrito sobre ele foi, na verdade, baseado em suas próprias memórias. Em outras palavras, a história sobre sua infância - e toda aquela parte no livro - foi ele quem ditou. Todo o processo de fato foi muito curativo para mim, realmente curativo. E finalmente acabei por aceitar - e escrevi isso naquele capítulo - que ele realmente era meu pai e que não havia problema em escrever seu memorial, o que acabei fazendo.

CEH: Há várias passagens do livro que são bastante emotivas. E é particularmente interessante a maneira como você aborda a linhagem materna, como sua mãe, avó e bisavó que foram escritoras, se engajaram em movimentos feministas, sufragistas e antiescravidão, além de lutas antirracistas... EN: Eu fiz algumas pesquisas sobre elas, é claro. Sabia algumas coisas, mas não possuía uma imagem coerente delas. A pesquisa que fiz sobre a questão me permitiu colocá-las em um contexto histórico, algo que era realmente importante para mim. E tenho muito orgulho do meu background esquerdista. Enfim, as pessoas geralmente se rebelam contra os pais. Quer dizer, eu certamente me rebelei contra meu pai. Ele queria que eu fosse psicóloga, o que eu não desejava ser. Mas, no que diz respeito à herança política dos meus pais, ela está intacta em mim. Minha mãe não era uma pessoa particularmente muito maternal. Ela era feminista no sentido de pensar que as mulheres deveriam ter os mesmos direitos dos homens, entende? Mas ela não estava envolvida no feminismo de segunda onda. Isso realmente me deu uma referência para me encaixar como uma feminista de esquerda. Houve um tempo, quando era muito jovem, que eu queria ser como uma garota popular da escola e lembro que minha mãe me disse: "De jeito nenhum! Daqui a alguns anos, ela viverá em um trailer com três filhos e você será professora universitária!" Ela possuía um monte de contradições. Era de esquerda, chegou a ser do Partido Comunista dos EUA, mas ao mesmo tempo ela costumava dizer que eu não deveria fazer aulas de espanhol, mas sim aprender francês, coisas do tipo.

CEH: Há algumas passagens especialmente interessantes em My Butch Career quando você aborda sua adolescência, a crise que enfrentava por ser uma garota mais masculina, que não se identificava com outras garotas. Há um momento em que você narra algo sobre estar trancada em seu quarto recitando o mantra: Tudo é relativo! Tudo é relativo! Você comenta que era a influência de Margaret Mead e Ruth Benedict, em seu próprio coming of age. Mead era imensamente popular nos meios de comunicação da época, eu imagino...

EN: Pensei durante muito tempo que li Coming of Age in Samoa no Ensino Médio, mas depois pensei que talvez tenha lido só na faculdade. Não tenho certeza, mas parece que devo ter lido no Ensino Médio mesmo porque, de outra forma, por que eu diria a coisa do "tudo é relativo" no meu quarto? Eu não sabia nada sobre Ruth Benedict até a faculdade. Mas Margaret Mead, li Coming of Age e lembro que minha reação foi: "Meu Deus do Céu! Minha situação é um produto da minha cultura!" Quer dizer, as coisas poderiam ser radicalmente diferentes e isso foi uma grande constatação. Estou falando dos anos 1950, mal havia alternativas. Havia algumas, na verdade: você era popular, estava no meio, ou era queer - que era como as crianças que não se encaixavam direito eram chamadas - e havia outra alternativa que era ser negra ou latina. E essas últimas eram tão ostracizadas! Elas eram tão segregadas, deixadas de lado mesmo. Por exemplo, a ideia de namoro interracial? De jeito nenhum! Então, na época, eu estava próxima de ser considerada queer e isso me deixava desesperada porque... eu era xingada, as pessoas gritavam ofensas. Era desagradável demais.

CEH: Posso imaginar. Especialmente em um contexto de macarthismo, patologização da homossexualidade, perseguição, coisas que você aborda em suas memórias. E quando você se mudou de Nova York para Palo Alto, Califórnia, na adolescência...

EN: Ah, isso foi um desastre! Exceto academicamente. Tive uma educação muito boa na Califórnia. Mas o Ensino Médio foi um pesadelo para mim, eu queria ser normal, queria me encaixar. Eu estava na Califórnia, era como um reino republicano, entende? Todo o resto foi horrível.

CEH: O capítulo "Baby Butch" em My Butch Career é particularmente incrível! Você menciona a questão em várias partes do livro, sobre a dicotomia butch e femme e os bares para lésbicas no Greenwich Village no final dos anos 1950 e ao longo dos anos 1960. Você também aborda questões de classe, raça, geração, sexualidade. Você acredita que as transformações sociais, digamos, no mundo lésbico da América do Norte, estão fazendo essa dicotomia butch x femme, e também a própria identidade lésbica de conjunto, meio que desaparecer hoje em dia?

EN: Essa é uma pergunta difícil. No processo de formação de identidade da época, no início da década de 1960, os limites de classe eram muito nítidos. Ou seja, butch e femme eram identidades principalmente da classe trabalhadora. Mulheres mais de classe média olhariam para mim e 
pensariam que eu era uma caminhoneira de verdade, sabe? E havia mulheres da classe alta, que é toda uma história bem diferente. Então, ainda há um pouco disso hoje em dia. Eu diria que o coração pulsante das identidades butch e femme ainda está na classe trabalhadora, mas o movimento de liberação gay sacudiu as coisas e as ampliou muito. O mundo lésbico antes disso era extremamente, digamos, segregado por classe e também por raça, é claro. O movimento de liberação gay sacudiu isso tudo. As pessoas começaram a conhecer mais pessoas diferentes das que estavam acostumadas. Houve um tempo em que o movimento de liberação gay e o feminismo lésbico concordavam em dizer: "Butch é uma coisa horrível! É como reproduzir papéis heterossexuais! Não queremos isso! É apenas um homem sem pênis! São como relacionamentos heterossexuais!" Nos últimos vinte anos, isso é meio que passé, um pouco passé hoje em dia. Eu passo meus invernos na Flórida e fiz uma leitura do meu livro de memórias na comunidade de aposentadas lésbicas em que vivo e muitas pessoas compraram o livro. Muita gente veio assistir. Mas depois percebi que certas pessoas estavam desconfortáveis. É preciso ter em mente que todo mundo que vive lá tem 65 anos de idade ou mais. Então, a maioria, ou muitas dessas mulheres, passou por um período em que pensavam que ser "butch é algo terrível", que "é apenas um papel heterossexual". Elas sabem que isso não é verdade, mas algumas pessoas que estavam assistindo fizeram um par de piadas inapropriadas. Surgiram coisas como: "As butches usam sutiã? Você pode carregar esse troço pesado, você é uma butch!" E essas são principalmente mulheres de classe média e de classe média baixa. Elas são, por exemplo, enfermeiras aposentadas, atuavam nas Forças Armadas, eram professoras de escola. Esses eram os empregos disponíveis para a maioria das mulheres da minha geração que queria ter um emprego em período integral. Ainda há muito desconforto em relação a esses tópicos. Recentemente vi uma matéria jornalística produzida pela $G Q$, aquela revista masculina. É uma matéria bem feita, bonita. Mostra cinco ou seis lésbicas diferentes, duas ou três delas são mulheres de cor [women of color] e dizem: "Eu sou butch!" E elas vestiam ternos e estão na casa dos quarenta anos. Então pensei, bem, acho que a identidade butch está continuando, ainda está bastante viva.

CEH: Você menciona em My Butch Career que, na década de 1960, a famosa manifestação feminista no concurso do Miss America teve um impacto maior em você do que a Revolta de Stonewall. Por que os impactos foram distintos para você? Tem algo a ver com a forte homofobia/ lesbofobia da época?

EN: Isso é verdade. Na época eu não me assumia como lésbica em minha profissão. Não saí do armário profissionalmente até 1974, depois que finalmente consegui meu tenure [uma forma de estabilidade profissional na universidade]. Antes disso, eu poderia ser tirada do armário e denunciada por algum/a estudante conservador/a. Estava muito vulnerável. Eu morava em Nova York na época e vi nos jornais sobre Stonewall. Lembro que pensei: "puxa, que coisa fabulosa!" Mas eu vi primeiro a manifestação feminista no Miss America ${ }^{19}$, em 1968. E realmente passei o ano seguinte procurando um grupo de liberação das mulheres que imaginei que pudesse me aceitar. Estava preocupada, mas depois de alguns meses eu encontrei um grupo. E alguns meses depois eu saí do armário para esse grupo. [Risos].

CEH: Você está falando sobre a WITCH ${ }^{20}$, não é?

EN: Sim, a WITCH. Antes de Stonewall, quando comecei a frequentar os bares lésbicos do Greenwich Village, adentrei na vida dos bares da classe trabalhadora, mesmo que elas me vissem como uma garota de faculdade, muito alienígena, mas elas me aceitaram. Então, nessa época eu comprei meu primeiro par de calças masculinas. Isso foi um grande acontecimento! [Risos]. Mas quando a revolta de Stonewall aconteceu, tudo mudou drasticamente. Depois disso, fiquei muito envolvida com a parte do movimento de liberação das mulheres. Mas também fui aos atos do

\footnotetext{
19 O episódio a que Newton se refere diz respeito ao antológico protesto ocorrido no Miss America 1969, mais especificamente no dia 07 de setembro de 1968. No evento reuniram-se centenas de feministas e ativistas pelos direitos civis e ali foram queimados em protesto diversos objetos tradicionalmente associados às mulheres. A queimada ocorria em uma lata de lixo onde se lia: "Freedom Trash Can" - algo como "Lata de Lixo da Liberdade". Esse evento televisionado contribuiu para catapultar às massas a ideia de "queimar os sutiãs" como ação simbolicamente representativa do movimento de libertação da mulheres dos anos 1960 e 1970, além de auxiliar a multiplicar exponencialmente a ałuação do movimento feminista em inúmeros cantos dos EUA e do mundo. As manifestações feministas no Miss America de 1968 auxiliaram a popularizar e a dar uma enorme visibilidade ao movimento feminista de segunda onda.

${ }_{20}$ W.I.T.C.H. é um acrônimo que significa: Women's International Terrorist Conspiracy from Hell (algo como Conspiração Terrorista Feminista Internacional do Inferno). O acrônimo, porém, por vezes é afirmado como dizendo respeito a: Women Inspired to Tell Their Collective History ou Mulheres Inspiradas a Contar suas Histórias Coletivas. Se tratou de um famoso grupo feminista da cidade de Nova York fundado no fim do anos 1960 e que reunia feministas socialistas, de esquerda, e que defendiam uma luta articulada não apenas contra o patriarcado, mas também contra outras formas de discriminação e de opressão, como as de classe e o racismo, além da defesa do movimento pelos direitos civis da época. Embora seja pouco frisado nas publicações que encontrei sobre o grupo, Newton afirma que este foi o primeiro grupo em que se sentiu segura e bem-vinda o suficiente para se se assumir lésbica dentro do movimento feminista.
} 
movimento de liberação gay. Logo depois de Stonewall - não lembro exatamente quantos meses depois - fui a algumas das primeiras reuniões. É interessante, pois eu tinha muito medo de estar lá. Imagine toda a vulnerabilidade que enfrentávamos naquela época. Todo esse contexto exigiu de nós muita coragem. Era preciso muita bravura para aquelas pessoas que fizeram as manifestações nessa época. As pessoas que marcharam com cartazes em defesa dos homossexuais em frente à Corte de Justiça da Filadélfia com placas dizendo: "Homossexuais também são cidadãos!". Não há nada mais corajoso que isso. Você não tem noção do risco que essas pessoas corriam ao participarem das primeiras marchas, das quais não participei, porque tinha muito medo de perder o emprego. Claro que há bravura entre ativistas jovens hoje. De todo modo, para além de toda essa coisa da coragem que comentei, na verdade não sinto falta de mais nada daquela época. Era muito difícil mesmo.

CEH: Nossa, com certeza, posso imaginar. Antes de falarmos sobre Mother Camp, gostaria de saber se você conhece um trabalho pioneiro que temos no Brasil de um sociólogo, José Fabio Barbosa da Silva, do final da década de 1950 (José BARBOSA DA SILVA, 1959). Ele também usou estudos etnográficos da Escola de Chicago como referência, para pensar em desvio e homossexualidade masculina, e apresentou sua monografia em 1959 na USP - Universidade de São Paulo. Seu trabalho se intitulava Homossexualismo em São Paulo e foi um dos primeiros trabalhos com uma abordagem etnográfica e não patologizante sobre homossexualidade na América do Sul. Há até algumas semelhanças em termos de abordagem teórica com seu trabalho em Mother Camp, mas uma década antes no Brasil. Você já ouviu falar desse trabalho? EN: Não, nunca ouvi falar. Mas parece algo muito muito interessante. Quando foi publicado?

CEH: Como livro, de fato, apenas no início dos anos 2000. Demorou meio século para ser publicado no Brasil, mas ele já havia publicado alguns artigos antes disso, por volta de 1960.

EN: Sim, o problema é que eu não sei ler em português, então... Caso contrário, eu provavelmente estaria ciente desse trabalho.

CEH: Entendo... Em várias partes de My Butch Career, é possível perceber a maneira afetuosa como você se dirige a David Schneider, seu orientador na Universidade de Chicago, e a longa e bela amizade que vocês tiveram.

EN: Depois que deixei Chicago, estabelecemos uma profunda amizade. Mas eu não chamaria de profunda amizade quando ele era meu orientador. Ele era meu mentor e um dos bons. Ele foi central para minha carreira. Mas Schneider foi crucial por várias razões. Era um risco tão grande para mim ou para qualquer um que ousasse fazer esse trabalho de campo com drag queens. As pessoas suspeitariam que eu era lésbica, mesmo que eu trabalhasse sobretudo com homens gays na época, e não com lésbicas. Eu não ousaria me associar profissionalmente a lésbicas na época. Temos que ter em mente que gays eram vistos nas ciências sociais como objetos de conhecimento médico ou, pior ainda, de estudos criminológicos. Portanto, toda a abordagem sobre homossexualidade ainda era muito baseada na ideia de anormalidades psicológicas. Schneider, de certa forma, sentiu que as female impersonators [transformistas] (e ele não sabia absolutamente nada sobre elas antes do meu trabalho), eram um grupo de seres humanos e, portanto, possuíam necessariamente uma cultura que valia a pena ser estudada. Porém, muito tempo depois que deixei Chicago, quando a esposa de Schneider já havia falecido, eu fui a Chicago para vê-lo. Fiquei muito triste com esse falecimento, pois gostava muito dela. Acho que foi quando ele me disse: "Me chame de David". Eu sempre o chamei de "Dr. Schneider" até então. E nos tornamos grandes amigos, amigos íntimos. De fato, ele decidiu deixar Chicago e se mudar para Santa Cruz, onde terminou sua carreira. E eu o visitei várias vezes, ficando na casa dele mais de uma vez. Ainda me lembro de sua biblioteca incrível e na última vez que o vi, ele me disse: "Quero que você dê uma olhada em meus livros e pegue o que quiser." E eu disse: "O quê!? Não!". Mas ele insistiu, então eu aceitei. Sabia o que ele estava dizendo. Foi um adeus e ele morreu não muito tempo depois disso.

CEH: Quando você demonstrou interesse em pesquisar drag queens em Chicago, recebeu algum tipo de conselho contra essa iniciativa na época? Para mudar de assunto ou algo do tipo? Qual era a posição de Schneider sobre o assunto?

EN: Eu estava interessada em fazer outra coisa. Antes de decidir fazer trabalho de campo com drag queens, eu planejava fazer trabalho de campo em Fiji. No começo, eu disse a mim mesma que só iria escrever um ensaio, um artigo final sobre as drag queens de Chicago. Mas então, quando mostrei a Schneider minhas anotações de campo, ele me incentivou a torná-las objeto de minha tese. E tenho que ser honesta: as drag queens me empolgavam muito mais do que fazer trabalho de campo em Fiji. [Ambos rimos]. Ele me disse: "Não! É isso que você deve pesquisar". Como eu disse, Schneider sentia que os gays não eram apenas uma categoria de indivíduos "doentes", mas um grupo e, portanto, eles tinham cultura. Na época, esse insight era tão importante, 
era algo mesmo extraordinário! Mas agora nós meio que tomamos isso como algo dado. Schneider me apoiou várias vezes. Eu era muito jovem e não tinha uma ideia de como o fato de escolher esse tema afetaria minha vida e carreira. Schneider era o chefe do Departamento e realmente acreditava que poderia me proteger, mas o problema é: ele não tinha ideia da mecânica da homofobia. $\mathrm{E}$, acredite ou não, ele não sabia na época que eu era lésbica! [Risos]. Claro, eu estava me esforçando muito para não ser rotulada como lésbica. Uma vez ele me disse que o Departamento estava realmente preocupado comigo porque eu estava usando calças demais. Ele disse: "as pessoas estão dizendo que você não está realmente comprometida com a antropologia". Dá para acreditar? [Risos]. O fato é que nós acreditávamos então na ideia de que vida pessoal e mundo acadêmico deveriam ser mantidos separados. Era uma ideia dominante na época. Isso me fez acreditar que ninguém se atreveria a me acusar publicamente de ser lésbica por ter homossexuais como tema da minha tese. Eu realmente não tinha ideia de que estudar female impersonators prejudicaria tanto minha carreira. Mas, ao mesmo tempo, essa decisão formaria a minha contribuição na minha obra escrita e também na docência. Não me arrependo dessa decisão. Então, de certa forma, Schneider me dizendo para estudar female impersonators foi o melhor conselho que já recebi, exceto que, se tivesse ido para Fiji, minha carreira seria... eu teria tido uma carreira muito mais brilhante do que a que tive.

CEH: Vejo sua carreira como brilhante. Mas entendo o que você quer dizer.

EN: Em 1968, quando terminei de redigir meu trabalho, minha banca de defesa de tese era composta por David Schneider, Julian Pitt-Rivers e Clifford Geertz. Sabe, nomes realmente grandes! E eles pediram apenas algumas pequenas revisões na tese. Na época, vários professores consideravam meu tema uma piada e ilegítimo, porque não tratava de "povos primitivos". É por isso que sempre ensinei a meus estudantes, décadas depois, que a primeira coisa que você precisa fazer é sobreviver! Eu sobrevivi. Vários professores diziam que meu trabalho não era realmente antropologia. Era uma situação muito difícil...

CEH: Posso imaginar, Esther. Sinto muito por ouvir isso. Que coisa terrível. A situação está diferente para nós hoje em dia por causa de pessoas como você. Mas, para ser honesto, às vezes ainda encontramos algumas figuras desse tipo em alguns departamentos de antropologia aqui e ali... EN: Sim... Fui provavelmente a primeira na minha turma a terminar minha tese, uma das pouquíssimas mulheres a fazê-lo. Vim de um prestigiado programa de antropologia, tinha um orientador poderoso. Meu futuro profissional tinha tudo para ser ótimo. Mas depois do doutorado eu trabalhei no sistema universitário da cidade de Nova York ${ }^{21}$. Depois de ser demitida - e essa foi uma situação terrível que menciono no livro de memórias - fui para o Purchase College no sistema do estado de Nova York. Ir para uma faculdade sem uma pós-graduação já é uma espécie de beco sem saída. Então, com o passar do tempo, começamos a ter mais e mais cortes no orçamento da universidade e a atmosfera ficou difícil. Realmente, não há muitas coisas que possam matar o moral do corpo docente e da equipe, como cortes contínuos no orçamento por anos seguidos. As pessoas que podiam partir foram embora. Mas eu não podia partir. Então é isso que quero dizer. Ninguém estava interessado no meu trabalho, pelo menos de que eu estivesse ciente, até muito mais tarde... Foi tudo muito difícil.

CEH: Essa situação toda afetou seus escritos também, eu imagino.

EN: Com certeza. Bem, voltando de verdade aos escritos e às revistas acadêmicas, foi com aquele artigo sobre a Radclyffe Hall (NEWTON, 1984). Foi a primeira vez que publiquei algo em muitos anos! Eu meio que havia desistido, queria abandonar a academia, na verdade. Mas não estava qualificada para fazer mais nada, quer dizer, isto era toda a minha vida, então... Mas a partir da década de 1980, sim, as coisas começaram a melhorar. Para dar um exemplo desse tipo de coisa, existe um grande e importante Departamento de Antropologia em Michigan. É onde Gayle Rubin está, somos velhas amigas. Quando cheguei lá, estavam tentando conseguir algum vínculo docente para mim, que na verdade era uma espécie de contratação casada. Em outras palavras, minha parceira conseguiu um emprego de professora em Michigan e dissemos: "E aí, há como conseguir algo para Esther? Então eu era uma espécie de contratação casada [second string], você conhece essa expressão?

CEH: Sim, sim, mas isso é inacreditável. Você como contratação casada? Parece tão improvável... EN: Então, era uma contratação casada. O Departamento de Antropologia poderia ter me dado o que é basicamente uma vinculação honorária onde não se recebe salário, é o que chamamos de compromisso seco [dry appointment]. Mas eles não o fizeram. Talvez eles pensassem que já possuíam uma professora queer. E não só isso, pois quando eu fazia uma fala pública, uma

${ }^{21}$ Esther Newton foi docente do Queens College da CUNY, em Nova York, por um curto período, no início dos anos 1970. 
conferência ou algo assim, Gayle Rubin era a única antropóloga que aparecia para assistir. Então, para profissionais de Antropologia, eu basicamente não era uma antropóloga de verdade, sabe? É isso que quero dizer quando afirmo que escolher esse tema de pesquisa prejudicou minha carreira, mas, por outro lado, acabou sendo algo muito significativo para mim e para todo um campo. Eu não queria trabalhar com coisas nas quais não estava realmente interessada.

CEH: Você escreveu no livro de memórias sobre as dificuldades do trabalho de campo em Mother Camp. Mas senti que foi uma experiência mais difícil do que você deixou escapar.

EN: [Risos]. Foi difícil. Muito difícil. Não havia treinamento real antes do trabalho de campo. Nada. Era mais como: "Ok, hora de ir para o campo!" Não havia nada! Eu li muitas etnografias, obviamente. E acho que escrevi no livro que uma das coisas mais importantes que Schneider me ensinou sobre o campo foi: "Escreva suas anotações todas as noites. E envie uma cópia para mim. Envie uma cópia carbono para mim toda semana". Tivemos um curso de métodos, um curso de pós-graduação com um sociólogo. O fato é que a maioria dos estudantes de pós-graduação da época não conseguia passar no curso de estatística... [Ambos rimos].

CEH: Não é tão diferente dos dias de hoje, me parece...

EN: Obviamente, tínhamos amplo acesso às etnografias, mas não às referências de como elas foram feitas em um sentido prático; não tínhamos ideia de como enfrentar situações difíceis e complicadas no campo. Na época, na década de 1960, havia cinco ou seis locais em Chicago para drag queens em bares gays. Aqueles caras me aceitaram principalmente porque pensaram que eu era lésbica devido à minha amizade com Skip ${ }^{22}$. Você sabe, o trabalho de campo estava centrado em circular pelos bares gays, assistindo aos shows de drag, fazendo entrevistas gravadas com eles entre os shows. Parecia que eu possuía um dom para ouvir, na época alguns costumavam dizer. Mas o trabalho de campo foi complicado pelas diferenças de classe. Em outras palavras: "ah, você é tipo uma professora ou uma estudante!" No meu trabalho de campo em Mother Camp eles me respeitavam, mas me viam como lésbica. Na época muitas pessoas da classe trabalhadora usavam aquelas expressões horríveis que você nem deveria mencionar, que nunca dizemos, mas que às vezes eles usavam carinhosamente? Você não pode mais dizer isso hoje em dia, coisas racistas, machistas e tal. As pessoas da classe média, quando eu era mais jovem, não ousariam dizer aquelas coisas. Mas as pessoas da classe trabalhadora sim. Tanto brancas quanto negras, tudo dependia do contexto, é claro, e de como você se sentia em relação à pessoa que estava dizendo aquilo. Por exemplo, no meu trabalho de campo, eles costumavam me chamar de fish [peixe]. Na época isso era uma gíria bem, bem pesada. Mas eles também gostavam de mim. Embora eu estivesse entre homens gays, ainda estava em uma cena dominada por homens. E eles costumavam me chamar de fish, assim, na minha cara, tipo, sem nenhum problema, sabe? Houve momentos em que eu estava realmente cansada de algumas dessas questões. Então isso foi uma coisa muito complicada. Certamente o fato de estar sozinha no campo era difícil. Mas eu estive lá por seis a nove meses em Chicago, e eu ainda morava no meu apartamento na cidade. A parte mais difícil foi ter que ir para Kansas City, onde fiquei em um hotel barato, estava realmente sozinha e não tinha minhas amigas por perto. Eu precisei me mudar para Kansas City para continuar fazendo meu trabalho de campo, pois Skip havia se mudado para lá. Comparado a Chicago, Kansas City era muito mais segura para female impersonators (transformistas) porque a máfia protegia os bares gays da cidade na época. Esse período foi difícil, mas ao mesmo tempo eu realmente gostava de ficar nos bastidores dos shows de drags.

CEH: Me corrija se estiver errado, mas parece que a recepção do Mother Camp não foi exatamente boa. Toda a reverberação do livro, as resenhas foram desanimadoras...

EN: Sim, não houve resenha alguma! Na verdade, havia apenas uma, mas descobri no ano passado que houve outra da época. Ambas as resenhas foram escritas por sociólogos, homens gays. A primeira foi feita por um sociólogo, um homem gay no armário. Ele era mais velho que eu e detestava a ideia de uma política de identidade. Meu livro era basicamente sobre a comunidade gay. Por isso, foi uma crítica muito dura, ele basicamente afirmou: "Ah, o livro está tão equivocado!". E na época eu pensei que isso era tudo. O livro foi publicado pela Prentice-Hall Press apenas porque David Schneider estava organizando uma série para eles, e conseguiu que Mother Camp fizesse parte. Mas depois de dois ou três anos eles simplesmente desistiram. O livro foi descontinuado e isso parecia ser o seu fim. Então, em 1970, eu já estava pensando: "Ok, sou um fracasso, ninguém está interessado/a no meu livro"... Eu acho que era 1978, David se tornou editor na editora da Universidade de Chicago e disse que queria reimprimir Mother Camp. Então eu aceitei, claro. E essa é a edição que, com o passar do tempo, eles mantiveram impressa e circulando. Rende uma

${ }^{22}$ Newton aqui se refere a Skip Arnold, um de seus interlocutores mais próximos em campo e, segundo ela, figura crucial para que ela adentrasse e fosse aceita no contexto da época entre drag queens e female impersonators (transformistas) de Chicago e Kansas City. 
grana todos os anos. Não é muito dinheiro, é claro, algumas centenas de dólares, mas rende todos os anos. Agora eles acham que é um livro realmente importante e não pensariam em abandonálo, obviamente.

CEH: Lendo o Mother Camp novamente, pude constatar que você já tentava analisar, à sua maneira, cruzamentos de gênero, sexualidade, raça, classe e idade/geração. Você vê seu trabalho de certa forma como precursor dos estudos sobre marcadores sociais de diferenças, por exemplo? EN: Sim, acho que é a mesma coisa basicamente. Apenas um nome diferente, mais chique e atualizado, digamos. Mas eu sempre tive consciência particularmente da classe social. Sem dúvida foi nisso que o feminismo - o feminismo de esquerda - me deu uma espécie de lente de análise e por isso eu nunca pensei que a única questão em jogo fosse o patriarcado, por exemplo. Essa não é a única coisa que importa. Mas é uma parte muito importante, é claro. [Risos]. Gênero, classe, raça e sexualidade. Quando fiz a coisa toda da saída do armário, senti a proximidade dos homens gays. Muitos dos meus amigos gays são muito importantes para mim. Foi apenas um breve período na minha vida em que eu pensei: "Homens são péssimos! Não quero nenhum deles na minha vida!" [Risos]. Isso não durou muito tempo. Homens gays têm sido uma parte muito importante da minha vida.

CEH: Há uma passagem em suas memórias na qual você faz um paralelo de sua própria experiência como lésbica butch, tendo que personificar o que significava ser mulher na época, lidando com toda aquela expectativa de feminilidade. Você menciona que essa experiência, de certa forma, não era tão diferente daquilo que as drag queens que você estudava costumavam fazer...

EN: Sim, foi isso mesmo que experimentei. O insight da performance. Quando os conheci, foi o que percebi: "nossa, eu sou como eles de uma maneira realmente importante!". Ao tratar as drag queens por uma perspectiva cultural, eu estava dizendo que os gays eram um grupo como qualquer outro, um tema adequado para a antropologia. Para isso, usei a antropologia simbólica e a literatura de desvio social da época. É claro que usei também muito da raiva que experimentei ao tentar me adaptar a uma ideia do que uma mulher deveria ser, ter que viver no armário como uma jovem lésbica, ter que lidar com insultos, medo, inseguranças. Eu me sentia próxima das performances das drags, entre outras coisas, porque isso era visto na época como parte da mesma "disforia de gênero", digamos assim, que vinha me atormentando. Como afirmei em Mother Camp, afinal, eu também estava praticando uma espécie de transformismo feminino [female impersonation]. Claro, de um tipo diferente. Escrevi também um artigo sobre isso (NEWTON, 1996).

CEH: Então, como você percebe o seu texto em Mother Camp hoje, depois de tantos anos? EN: Bem, a linguagem não é mais a mesma, mas na época era algo muito avançado, muito vanguardista. Sinto que o livro ainda é muito acurado para o que eu estava olhando. Muito preciso mesmo. Penso que foi algo muito arguto. Que minhas análises foram boas. Eu penso que ainda é um ótimo livro. É algum tipo de ancestral do que temos hoje. A história é tudo, você não sabe quem você é, a menos que saiba de onde veio.

CEH: E o que você pensa das mudanças atuais no mundo das drag queens, sabe, reality shows como RuPaul's Drag Race e toda a indústria cultural sobre artistas drag?

EN: Fico impressionada hoje em dia com a forma como o fazer drag proliferou de uma maneira fascinante. Todos esses artistas incríveis levaram tudo a um outro nível. Mas, ao mesmo tempo, para dizer bem a verdade, às vezes me parece que, no seu cerne, ainda é em grande medida o mesmo tipo de drag que analisei nos anos 1960.

CEH: E como você vê as leituras contemporâneas de Mother Camp que repensam as experiências que você analisava em um quadro transgênero? Você acredita que tais leituras poderiam ser vistas como anacrônicas?

EN: Ninguém naquela época, nenhuma das queens, se identificava como transgênero [transgender], porque essa palavra nem existia. De fato, houve algumas pessoas que se identificavam como transexuais [transsexuals], e havia um debate na época do tipo: "Pode um performer drag se identificar como transexual?". Porque o ponto principal do fazer drag era que você era "um homem que usava um vestido". E isso era a coisa interessante para eles, o que era dito na época. Essa situação mudou drasticamente nos dias de hoje, é claro.

CEH: Você é uma pioneira nos estudos de gênero e sexualidade e nos estudos LGBT. Na verdade, algumas pessoas agora estão reposicionando você como precursora dos estudos queer. Mas esse pioneirismo teve um custo. Especialmente o que aconteceu em seu primeiro emprego no Queens College. Aquela demissão pareceu ser um episódio realmente traumatizante e afetou 
profundamente sua carreira. Li recentemente outro episódio de machismo institucionalizado, mas com outra pessoa, Louise Lamphere...

EN: Louise Lamphere? Mas ela não é lésbica ...

CEH: Ela escreveu uma texto em 2009 falando sobre ter sido demitida da Brown University em 1974, basicamente por ser feminista ${ }^{23}$.

EN: Sério? Eu não sabia disso.

CEH: Ela afirma que foi demitida em 1974 por essa razão, abriu uma ação contra a Universidade e venceu. Então ela foi contratada de volta e houve várias consequências interessantes para essa vitória em termos de questões e direitos relacionados a relações de gênero (Louise LAMPHERE, 2009). Imagino que para você na época, como lésbica e feminista, deve ter sido particularmente complexo lidar com essas questões.

EN: Bem, acho que no Queens, enquanto trabalhava lá, eu era uma feminista explícita, porém, não uma lésbica assumida. Quando você é obviamente gay, principalmente naquela época, você ameaça as pessoas. Eu não disse que era gay, mas eles sabiam que eu era e não se sentiam confortáveis com isso. Quer dizer, é o que imagino que tenha acontecido nos bastidores. Isso ainda acontece hoje em dia até certo ponto. Agora estou muito mais confortável comigo mesma. Você sabe, agora eu digo: "Esta é minha esposa"; "Eu sou butch", sabe? E isso de certa forma deixa as outras pessoas à vontade hoje em dia. Digo, pessoas heterossexuais. Sabe, eu escrevi esse livro de memórias também porque queria passar essas experiências para sua geração e gerações depois de você de onde nós viemos.

CEH: Sim, isso é crucial. Autoras como Gayle Rubin e Judith Butler reconhecem as contribuições centrais de sua produção. Rubin, em particular, afirma que não teria desenvolvido seus escritos - os debates sobre sexo e gênero, o conceito de gênero, as discussões sobre as políticas sexuais - da mesma maneira sem o seu trabalho em Mother Camp. Butler diz algo semelhante e credita o seu primeiro livro como central para sua teoria da performatividade de gênero. Você acredita que os trabalhos dessas autoras foram importantes para o reconhecimento de sua obra nas últimas décadas? EN: Tenho certeza que ajudou, definitivamente. Mas também havia forças maiores em ação. Quero dizer, na década de 1980, os editores começaram a se interessar por outros tópicos. Eles perceberam que havia uma audiência para tópicos negligenciados. Eu acho que é um pouco semelhante ao que aconteceu com outras minorias em termos de publicação de temas em que, a princípio, não havia quase nada. Então eles descobriram: "Nossa, há uma audiência negra por aí!". E esse é o estágio em que queers ainda estão. Porque a próxima etapa é, tipo, muitas/os autoras/es negras/os transcenderam isso para se tornar... Bem, Toni Morrison é um ótimo exemplo. Agora, existem muitas/os autoras/es mais jovens que são bem relevantes na literatura. E que não são vistas/os ou rotuladas/os como apenas para pessoas afro-americanas. Não apenas para o público negro. Mas ainda não estamos lá. Digo, nós queers. Especialmente lésbicas. Os gays estão em uma situação um pouquinho melhor. Então, ainda estamos nessa caixinha sobre a qual falei antes.

CEH: Quero perguntar sobre um artigo de Rubin (2016) chamado "Geologias dos estudos queer", no qual ela diz que há um processo de apagamento de contribuições anteriores para estudos queer e LGBTIQ. Como se trabalhos anteriores não fossem realmente cruciais para abrir caminho para trabalhos posteriores nesses campos. O que você pensa do ponto de vista dela e o que você pensa também dos estudos queer contemporâneos em geral?

EN: Bem, de uma perspectiva mais ampla, os norte-americanos não estão realmente interessados em História. Porque somos encorajados a pensar que: "Sou um indivíduo único! Você pode se criar do nada!" E coisas do tipo. E isso é tão errado! Para entender a si mesmo/a, você realmente precisa entender de onde veio. Mesmo se você discordar em um determinado ponto. Eu acho que isso é crítico sobretudo nas comunidades queer, mas é muito difícil também porque sociologicamente não há muita interação entre gerações. Quero dizer, fora da academia, estudos queer e estudos sobre mulheres, onde existe uma interação entre pessoas mais velhas e mais jovens? E esse tipo de interação

\footnotetext{
${ }^{23}$ A antropóloga feminista Louise Lamphere, em um artigo curto de 2009, narra a batalha judicial contra a Brown University e seu Departamento de Antropologia em 1974. Naquele ano ela foi informada por seu superior de que não teve o seu pedido de tenure aprovado e, portanto, teria que abandonar a instituição em até um ano. Ela narra que sua avaliação profissional ocorreu pelos seis homens de seu departamento e que o famoso livro que coeditou com Michelle Rosaldo, Woman, Culture and Society (1974), visto como um dos fundadores da antropologia feminista, foi considerado por boa parte de seus colegas como tendo uma "orientação teórica extremamente frágil" (LAMPHERE, 2009 , p. 09). Ao longo do texto Lamphere narra de maneira eletrizante o modo como conseguiu reunir provas sobre a óbvia discriminação de gênero que sofreu e como conseguiu vencer o processo e ser readmitida em seu emprego com o direito a estabilidade. Tal processo também gerou uma multa milionária à Brown por discriminação de gênero e se tornou uma espécie de jurisprudência que transformou a lida com direitos das mulheres em muitos departamentos acadêmicos da época.
} 
é algo que sempre amei. Mas, em geral, há uma enorme segregação etária, bem como de classe, raça e gênero, todas essas coisas. É diferente do passado, mas ainda está acontecendo. E entre pessoas queer também. Então, cada grupo, digamos, pensa que a maneira que fazem é a maneira que deve ser. Às vezes, as pessoas não tomam um tempinho sequer para perceber como outras pessoas, contemporaneamente, mas também do passado, tiveram que lidar e superar as coisas. Elas não sabem sobre os ombros de quem elas se apoiam. E há um tremendo desrespeito por pessoas idosas. Porém, na verdade, ouvimos a mesma coisa da comunidade afro-americana e de algumas/uns de suas/seus intelectuais, sabe? Coisas como: "Esses jovens, eles não sabem sobre o movimento dos Direitos Civis, não sabem como sofremos!". E assim por diante. E penso que há muita verdade nisso. Porque é a mesma coisa no mundo queer. Eu acho que isso limitou muitas coisas para pessoas queer e negras. Nossa história não é ensinada antes do ensino superior, e deveria ser ensinada desde o início. É por isso que alguns jovens afro-americanos não estão tão conscientes da luta pelos Direitos Civis, porque não são ensinados. Nós, queers, temos o mesmo problema, principalmente por causa de questões religiosas. Sinto que recordar o passado é crucial para não reinventarmos a roda. Hoje em dia é muito comum ver pessoas escrevendo coisas do tipo: "Oh, essas ideias nunca aconteceram antes!". Isso também torna várias/os jovens muito arrogantes. Eu também experimentei isso quando era jovem, é claro. Me lembro de como me sentia sobre o feminismo do século XIX, as sufragistas e tal. Portanto, este é um problema contínuo. Todo esse processo de um esquecimento cíclico. Eu acho que Gayle Rubin tem razão. Ela afirma que temos que ser institucionalizadas/os, quer dizer, precisamos defender departamentos e instituições para preservar nossa memória como queers. Nada dura se não for institucionalizado. Sempre farei parte do movimento de onde vim. O primeiro momento do movimento foi no início dos anos 1950, com a Mattachine Society. Minha consciência de que havia de fato um movimento, porém, veio de tomar conhecimento da criação das Daughters of Bilitis em 1955. Eu costumava receber a revista produzida por elas: The Ladder. Costumava vir com um envelope marrom para que, se alguém o visse, eu pudesse dizer que estava relacionado a coisas profissionais. Na época isso era muito, muito arriscado. É claro que hoje os estudos queer mudaram para uma direção diferente, a qual não é assim tão interessante para mim, por assim dizer. Eu não estou tão interessada em teorias sobre teorias. Estou interessada em significados associados às ideias reais das pessoas. Então acho que posso afirmar isso.

CEH: Depois de publicar Mother Camp, você escreveu um livro com uma amiga, Shirley Walton, intitulado Womenfriends, em 1976. Poucas pessoas mencionam esse trabalho. Parece que você, à sua própria maneira, já estava tentando mostrar que o movimento feminista precisava abordar outras questões dentro da categoria "mulheres", particularmente as questões lésbicas. De certa forma, parecia uma iniciativa que se coaduna com o que mais tarde seria chamado de instabilidade sobre o sujeito do feminismo. Uma crítica análoga estava sendo apresentada ao mesmo tempo, mas a respeito de raça, gênero e classe, por teóricas feministas afro-americanas. Você poderia falar um pouco sobre esse livro tão pouco conhecido? Como ele foi escrito e sua amizade com Shirley Walton?

EN: É algo por aí... Shirley foi minha melhor amiga por cinquenta anos. Ela faleceu há cinco anos. Nós éramos colegas de faculdade e moramos juntas em nosso primeiro ano de graduação e continuamos sendo amigas íntimas. Nós duas nos mudamos para Nova York e ela se casou. Ela se casou quando eu estava começando a ter relacionamentos sérios com outras mulheres. Conversávamos sobre muitas coisas pessoais, mas nós nunca havíamos realmente conversado sobre o que significava o fato de ela ser heterossexual e eu ser lésbica. E então, quando o feminismo lésbico começou a se desenvolver, comecei a me questionar: "Por que sou amiga dessa mulher hétero?!" [Risos]. Então esse livro era sobre tentar resolver essa questão entre nós. Como eu disse, sempre guardei diários, então minha parte nesse livro foi meio que o meu diário durante esse período. Tivemos a ideia de escrever este diário conjunto, mas meio que uma respondendo à outra. Estávamos abordando nossa vida cotidiana, mas também estávamos respondendo uma a outra e dialogando. Nós o escrevemos e acho que hoje é um documento super interessante, um documento histórico da época. Mostrando alguns dilemas do feminismo de então. E nós superamos a questão. Continuamos amigas até ela morrer.

CEH: Você mencionou em suas memórias duas grandes decepções na década de 1970: a recepção de Mother Camp e o que aconteceu no Queens College na CUNY, depois que o seu primeiro pedido de tenure foi negado. Depois disso, você parece ter se direcionado para reflexões mais, digamos, feministas, atuando fora da academia. Womenfriends, de 1976, parece representativo deste momento, não é? Pouco tempo depois, você saiu de Nova York e se mudou para Paris, onde viveu por cinco anos...

EN: Sim, exatamente. Nessa época eu meio que desisti da vida acadêmica. Houve um tempo em que sentia algo como um: "Foda-se a academia!" E fui a Paris para escrever um romance. Fiquei em Paris por cerca de seis anos. Pensei seriamente em abandonar a antropologia e a academia 
como um todo. Nesse momento eu decidi: "bem, eu adoro escrever", estava claro para mim na época e pensei em fazer isso. Pensei: "vou escrever um romance!". Essa foi minha ideia. Na verdade, eu estava profundamente apaixonada por uma francesa e cogitei mesmo desistir de meu cargo [tenure] na Purchase e me mudar para Paris. Mas no fim das contas eu era classe média demais e simplesmente não dei conta disso. Se sustentar como norte-americana em Paris definitivamente não era fácil. Eu não conseguiria um emprego de verdade em tempo integral na academia lá. Pelo menos não naquele momento. Talvez se eu ensinasse inglês como segunda língua, ou algo assim. No fim, me sinto feliz por ter tomado essa decisão. Eu não poderia deixar meu emprego com estabilidade. Você nunca sabe onde esse tipo de decisões irá te levar.

CEH: Enquanto vivia em Paris, você teve um envolvimento no movimento feminista parisiense da época, entrou em contato com Monique Wittig, Hélène Cixous, Antoinette Fouque e outras feministas francesas importantes da época. Você as menciona em suas memórias, mas isso foi algo breve no livro. Você pode falar um pouco sobre isso?

EN: Na verdade, escrevi muito sobre isso nas memórias, mas as pessoas me diziam: "Tem coisa demais sobre a França no livro!". E me diziam: "Corte isso! Corte isso!". O que odiava fazer, mas tenho tentado ficar tranquila com essas escolhas agora. Estou enviando meus arquivos para a Universidade de Michigan ${ }^{24}$, e talvez algum/a estudante de graduação no futuro possa trabalhar nisso. Porque eu escrevi muito sobre esse período. Viver em Paris foi tão interessante para mim. Não sei se disse isso no livro, mas Margaret Mead uma vez me disse pessoalmente: "Se você não faz um trabalho de campo no estrangeiro, você não é uma antropóloga de verdade!". Acho que isso é uma ideia muito escrota [a pretty fucked up idea], mas devo dizer que morar na França me fez entender - é claro, tudo dentro de culturas europeias - como a linguagem é importante para a diferença cultural. Porque se não houver uma palavra para uma determinada coisa, você não pensa nela. Para além disso, já foi uma grande experiência para mim somente estar em Paris. Quanto ao feminismo, isso também era muito diferente do que eu havia experimentado em Nova York. Havia semelhanças, é claro, porque, por exemplo, o feminismo anarquista em Paris tinha similaridades com o feminismo cultural nos Estados Unidos. Mas o outro grupo, aquele com Antoinette Fouque, não possuía algo análogo. E ambos eram grupos muito diferentes. Eu estava, de certa forma, um tanto desiludida com o feminismo. Porque, na década de 1970, o movimento começou a ir para uma direção com a qual eu realmente não me identifiquei. Então, em termos pessoais, minha amante francesa estava entrando no feminismo enquanto eu estava meio que me afastando do movimento. Isso causou problemas em nosso relacionamento. Mas ainda somos amigas. Dominique está com 87 anos agora. Nos vimos algumas vezes nos últimos dez anos e conversamos bastante por telefone.

CEH: A maneira como você a aborda nas memórias é muito intensa e interessante. Há outro episódio que você não desenvolve muito em suas memórias. O Seminário do Barnard College sobre Sexualidade das Mulhere ${ }^{25}$ em 1982. Você o abordou muito brevemente. Esse seminário foi um divisor de águas para você, não foi?

EN: A Conferência do Barnard College foi definitivamente um ponto de virada para mim. A conversa que estava sendo feita por Gayle Rubin naquela época foi central. Uma coisa que me chocou foi que ela saiu do armário para mim como participante de S\&M [sadomasoquismo]. E eu fiquei tipo: "Sério?! Com esse rostinho angelical?!" [Risos]. Na época eu pensava que isso era coisa de caras, sabe? De caras gays. Isso meio que abalou meu mundo e conversamos sobre suas opiniões acerca dos equívocos que o feminismo até então havia cometido. Aquilo ressoou em mim sobre, de certa forma, equiparar ideologias acerca da sexualidade e ideologias feministas. Há muito tempo pensava nisso e me debatia com a questão. Minhas referências naquela época eram Gertrude Stein e Alice B. Toklas, e eu sabia que esse arranjo estava de alguma maneira errado do ponto de vista feminista - digo, do ponto de vista feminista da época -, mas elas eram esse casal intelectual de lésbicas e essa era a vida que eu queria e não sabia como alcançar.

CEH: Foi aí que você se tornou parte do que mais tarde seria a SOLGA na American Anthropological Association? Por que esses episódios não estavam mais abordados em suas memórias? Foi parte de todo esse processo de edição que você mencionou anteriormente?

\footnotetext{
${ }^{24}$ Newton afirma que seus arquivos pessoais foram cedidos por ela mais especificamente à Coleção Labadie (Labadie Collection) na Hatcher Graduate Library, na University of Michigan na cidade de Ann Arbor. Uma qutora que põe em relevo o caráter central dessa importante coleção para os seus próprios estudos sobre gênero e sexualidade é Gayle Rubin $(2016,2018)$.

${ }^{25}$ O Barnard College Seminar on Women's Sexuality (Seminário sobre Sexualidade das Mulheres realizado no Barnard College) em Nova York em 24 de abril de 1982, foi um importante evento que promoveu um debate sobre a sexualidade feminina tensionando, entre outras questões, as relações entre prazer e perigo nas teorias feministas e nas vidas de mulheres nos Estados Unidos. Tal conferência foi bastante influente tendo incidido nas guerras sexuais feministas da época e em discussões, por exemplo, sobre agência, desejo, prazer, pornografia e práticas BDSM (Bondage, Dominação e Sado-Masoquismo). Sobre o assunto, consultar Vance (1984) e Rubin (1984).
} 
EN: Isso é verdade. Mencionei brevemente. Esse seminário e a SOLGA, depois que voltei de Paris para Nova York, meio que abriram o caminho para que eu retornasse à academia. Sou muita grata por isso, porque toda a segunda parte da minha carreira foi muito diferente e bem melhor. Foi quando eu conheci Amber Hollibaugh, que se tornaria minha parceira por alguns anos. Foi quando li seu ensaio Rolling around in bed with ${ }^{26}$... que me influenciou muito! Entrei em contato pela primeira vez com esse texto na Conferência do Barnard e então retomei a ideia de ser uma butch. Me influenciou a pensar que havia uma maneira de reconfigurar essa identidade, que não era necessário ser algo tão rígido e que não havia nada intrinsecamente errado naquilo. Isso foi muito libertador para mim. Algo na ira de Amber me comoveu e esse foi um episódio muito importante. As mulheres começam com uma grande desvantagem, porque em geral não nos é ensinado nada em termos de sexualidade. O pessoal é político dizia respeito originalmente ao fato de seus problemas pessoais - algo que você percebia como meramente um problema pessoal - na verdade estarem inseridos em toda uma conjuntura política mais ampla. E isso é uma ideia muito familiar a cientistas sociais, certo? Captei isso quase imediatamente por causa dessa questão. Mas dentro do movimento lésbico da época, o significado para o pessoal é político foi distorcido para: se você é uma butch, não pode ser lésbica. Ou, se você usa salto alto, não pode ser lésbica, ou se é do Partido Republicano, não pode ser lésbica. Infelizmente, lésbicas também podem ser republicanas! [Ambos rimos]. Tornou-se esse tipo de polícia moral, polícia do vestuário, sabe? E eu sinceramente não penso que isso seja algo tão expressivo no mundo dos homens gays. Então essa era a direção que as coisas estavam tomando e eu realmente não gostava disso. A SOLGA era algo estritamente entre acadêmicas/os, no contexto antropológico. Já a Conferência do Barnard também era para outras feministas, não necessariamente antropólogas, e algumas eram lésbicas, mas a maioria, na verdade, não era. De fato, a coisa era sobre sexualidade, sexualidade feminina, mas eu me recordo de um episódio em que Ellen Willis, uma feminista de esquerda, em uma reunião em Barnard, afirmou: "Gente, por que estamos falando tanto de lésbicas?!" [Risos]. E eu disse: "Sabe, esta é uma conferência sobre SEXUALIDADE!" [Risos]. Quer dizer, ela estava questionando "Por que estamos falando tanto dessa coisa sobre as lésbicas!?".

CEH: Ela disse isso?

EN: Sim! [Risos] Você sabe, e isso foi em 1981, eu acho.

CEH: Acredito que a Conferência foi em 1982.

EN: Gostei de você! Parece que você realmente fez o dever de casa ao pesquisar a minha carreira! [Risos].

CEH: Ah, com certeza. Como eu disse, em meus estudos de graduação e pós-graduação fui orientado por antropólogas feministas da UFSC e Unicamp no Brasil. É claro, eu precisava estar preparado, é meio que uma oportunidade única na vida. Bom, estamos indo para o final da entrevista. Vamos falar um pouco sobre o seu terceiro livro, Cherry Grove, Fire Island (1993). Nessa etnografia você possuía muitos/as interlocutores/as que eram na verdade idosos/as. Em particular o seu relacionamento com Kay é muito interessante. Era uma relação de trabalho de campo tão bela e, de certa maneira, também uma abordagem pioneira ao tratar com honestidade questões como erotismo, atração sexual e sexualidade em campo. Considerando que atualmente faço meu trabalho de campo sobre envelhecimento, gênero e sexualidade - particularmente com "idosos/as LGBTIQ" - você poderia falar um pouco mais sobre esse livro, seu segundo trabalho de campo e, particularmente, sobre as relações intergeracionais nesse livro?

EN: Bem, agora eu entendo algo que me diziam na época. Minha ideia era, você sabe, primeiro você entrevista ' $X$ ', depois você entrevista ' $Y$ ', você entrevista ' $Z$ ' e assim por diante. E alguém teve a ideia, pode ter sido Kay, de reunir um grupo para falar sobre os velhos tempos. Agora eu entendo por que eles/as queriam fazer isso. É porque todos/as estavam preocupados/as com suas memórias. E eles/as se divertiram muito recordando juntos/as. Eu fiz dois grupos distintos e eles/as adoraram. Foi também uma desculpa para que todos/as se reunissem, conversassem sobre seus dias de juventude. Há muitas coisas que aprendi com eles/as que me afetam agora. Eu estou hoje na

\footnotetext{
${ }^{26}$ Aqui ela se refere ao influente artigo "What we're rollin around in bed with. Sexual silences in feminism: a conversation toward ending them" (1983 [1981]) escrito, na verdade, a quatro mãos por Amber Hollibaugh e Cherríe Moraga. Debatido primeiramente na referida Barnard Conference, o texto aborda criticamente o que as autoras chamam de "falha do feminismo em endereçar as questões da sexualidade das mulheres", a qual seria similar à "falha do movimento homossexual em levar em consideração as questões relacionadas a gênero". As autoras, debatendo de maneira articulada gênero, sexualidade, raça e classe, produzem no artigo uma escrita contextualizada na qual se localizam como mulheres e lésbicas, uma branca e a outra chicana, e ambas provenientes de classes trabalhadoras. HOLLIBAUGH, Amber; MORAGA, Cherríe. "What we're rollin around in bed with. Sexual silences in feminism: a conversation toward ending them". In: SNITOW, Ann; STANSELL, Christine; THOMPSON, Sharon (eds.). Powers of Desire: the politics of sexuality. New York: Monthly Review, 1983, p. 394-405. Disponível em: http://freedomarchives.org/Documents/Finder/ DOC46_scans/46.WhatwereRollinAroundinBedWith.pdf. Acesso em: 02/03/2020.
} 
idade em que eles/as estavam na época. Eu sempre amei estar perto de pessoas mais velhas. Eu sou uma antropóloga histórica. Eu quero aprender o que você está fazendo agora. Mas quero também aprender como era antigamente para você, sabe? Não apenas o presente, mas também o passado. Como você administrou sua vida, como encontrou o amor, que tipo de trabalho você tinha que agora não precisa fazer mais nada? [Risos]. Alguns/mas deles/as realmente eram super ricos/as. Havia tão pouca história escrita sobre o Grove. E eu só tinha um assistente de pesquisa que era um estudante de graduação, um rapaz gay. Ele me ajudou muito, foi ao escritório do Fire Island News e desenterrou artigos antigos e coisas assim. Com as drag queens, em meu primeiro trabalho de campo, eu não sabia nada sobre a história delas. E as pessoas com quem eu estava lidando na minha primeira etnografia eram homens jovens e de meia idade. Bem, havia dois homens mais velhos. Mas no geral eles eram mais jovens do que no meu segundo trabalho de campo em Cherry Grove. E as drag queens sabiam um pouco sobre a história, história oral, mas não consegui encontrar nada escrito sobre elas na década de 1960. Por outro lado, no Grove, a princípio, era a mesma situação. Eu fui lá primeiro como turista, na verdade. Só para poder estar em um lugar gay. E então comecei a pensar: "como esse lugar se tornou o que é? Como essas pessoas formaram essa comunidade incrível?". Como não pude fazer muita pesquisa na biblioteca, a maneira de descobrir era sobretudo a história oral. E quem conhece a história oral melhor que pessoas idosas? [Risos].

CEH: Um de seus ensaios, My Best Informant's Dress (1993), é realmente fascinante para essa discussão. Você acredita que, desde então, as coisas avançaram na antropologia em relação aos debates sobre erotismo e sexualidade em campo?

EN: Bem, eu não estou mais nessa. Eu sou muito dedicada à antropologia como um quadro intelectual, mas não tanto à parte institucional dela. Na verdade, não tenho lido mais antropologia. Posso dizer que fiquei muito decepcionada com toda a coisa reflexiva que aconteceu na antropologia nos anos 1980 e li todos aqueles trabalhos. Não era nada parecido com o meu trabalho. Era sobre "eu", muito "eu" e... Enfim, era preciso pensar em "eu", "eu" e "quem sou eu"... Havia algo que realmente eu não gostava sobre isso na época. Esse ensaio, My Best Informant's Dress, não era apenas sobre "eu". Foi dirigido especificamente a antropólogas/os. Mas era sobre a questão da sexualidade no campo e acabou endereçando o contexto do trabalho de campo ao qual eu me referia. Então, eu realmente não sei se as coisas progrediram mais. O que eu sei é que muitas pessoas realmente gostaram desse ensaio. E parece que foi influente, eu acho.

CEH: Você disse que não está mais lendo antropologia. Porém você teve contato com antropólogas/ os mais jovens como Kath Weston, Tom Boellstorff, Gloria Wekker, Margot Weiss, Marcia Ochoa, Martin Manalansan e seus trabalhos?

EN: Alguns/mas deles/as, sim. O que na verdade aconteceu depois que lançamos a SOLGA na década de 1980, é que havia todos/as esses/as estudantes de pós-graduação por aí que não tinham ninguém para orientá-los/as intelectualmente. Eles/as poderiam ter alguém para ajudálos/as em termos práticos em seus departamentos. Mas eles/as não possuíam ninguém em seus departamentos que soubesse o que eles/as estavam tentando fazer, mesmo sendo solidários/as com eles/as. Não era o campo desses/as orientadores/as, porque na época não havia exatamente um campo sobre a questão na antropologia. Pessoas como Tom Boellstorff, David Valentine, Kath Weston, sabe? Muitas pessoas que você nomeou gravitaram ao nosso redor. Na época nós já éramos a "geração mais velha". Estávamos na casa dos cinquenta, eu acho. Eles/as gravitavam no nosso entorno porque nós entendíamos o que eles/as estavam tentando fazer. Então foi assim que eu conheci todas essas pessoas. Penso ter lido os seus trabalhos. Na verdade, eu fui leitora inclusive de alguns de seus manuscritos. Pelo menos os trabalhos mais antigos. Mas agora realmente não tenho mais acompanhado isso.

CEH: Houve uma passagem interessante em My Butch Career em que você abordou diferenças geracionais em relação a questões de identidade de gênero. Você trouxe à tona e discutiu particularmente a questão de ser uma mulher lésbica e ser questionada sobre por que você não se considera um "homem trans" e a razão de não ter feito a transição de gênero. A maneira como você fala sobre isso me pareceu muito interessante...

EN: Sim. Houve inúmeras vezes em que fui confundida com um homem. Até hoje, na minha velhice, ainda acontece com frequência. No centro de saúde geriátrica que frequento, por exemplo, alguém me interpelou há um tempo atrás: "Você sabia que entrou no banheiro feminino?". Não havia uma saída fácil, então eu respondi: "Sim, sou uma mulher! E eu sei ler!" [Risos]. Quando eu era bem mais jovem, sabia sobre a Christine Jorgensen. Ela fazia parte - quando ainda era vista como homem - do exército dos EUA. Isso foi na década de 1950, eu acho. Foi realmente a primeira grande transição pública de gênero. Ela foi para a Dinamarca e passou por uma cirurgia, na época era algo praticamente experimental. E voltou como Christine Jorgensen. Havia uma enorme 
publicidade e eu certamente fiquei muito interessada, mas nunca pensei que aquilo fosse para mim e que pudesse de fato fazer isso. A transição de gênero feminino-para-masculino só começou a ser realmente conhecida no mundo das lésbicas a partir dos anos 1990. Eventualmente tive que encarar o fato de que se eu fosse criança agora e se tivesse internet, sabe? Todos os sites prótransição de gênero na web, eu provavelmente pensaria que isso era para mim. Porém, por outro lado, não há muitas pessoas na web dizendo: "Eu sou uma butch! Aqui estão fotos do meu corpo. E aqui está minha namorada!", sabe? Isso já não está na crista da onda. Uma das coisas que eu queria fazer com My Butch Career era também abrir espaço para as pessoas terem mais opções. Para não pensar que as pessoas necessitam fazer a transição para viver a sua masculinidade. E não sou anti-trans, obviamente. De modo algum. Eu penso que provavelmente a existência de homens trans antigamente teria tornado as coisas muito, mas muito mais fáceis para mim. E também tenho muitos problemas em comum, como eu disse, quando vou ao banheiro feminino. Nunca ligaram para a polícia por causa disso, mas estou sempre um pouco ansiosa perto de banheiros. Na verdade, penso que há muitas questões que se sobrepõem e, eventualmente, com todo o movimento não-binário que vem acontecendo, que o gênero está meio que sendo reconfigurado e que, eventualmente, existirão novas transformações. Quer dizer, se alguém me perguntasse: "Você é trans?". Eu poderia dizer: "Bem, depende do que você quer dizer com isso". Essas são algumas das coisas no livro que fico realmente feliz por ter discutido. E fiz um esforço de verdade para escrever sobre sexo também...

CEH: Sim, de uma maneira belíssima. Existem passagens incríveis sobre isso.

EN: Obrigada. Li recentemente dois livros de memórias de escritoras lésbicas. Um deles se intitula In Search of Pure Lust [de Lise Weil, publicado em 2018], o qual descreve todos os tipos de assuntos, mas então ela diz: "E então fizemos amor!", sabe? Nenhuma tentativa de descrever de fato o que estava acontecendo sexualmente. Ou o que ela desejava de um relacionamento sexual. Porém, para dizer a verdade, é difícil. É muito difícil, porque não temos realmente um vocabulário para descrever com facilidade o que pretendemos...

CEH: Entendo. Tendo em mente que você não menciona grande parte da segunda parte de sua vida em suas memórias, as pessoas não ficam sabendo muito sobre sua paixão pelo esporte

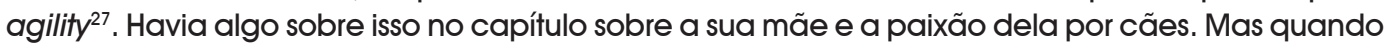
todo esse amor pelo agility começou de verdade?

EN: Bem, desde que eu era muito jovem, minha mãe sempre amou cães. Ela chegou inclusive a escrever um livro premiado sobre eles. A coisa é que eu também sempre amei cachorros. Quando eu era novinha, nunca senti algum tipo de competição com os cães, mesmo que minha mãe tenha de fato me negligenciado por eles. Quando nos mudamos para a Califórnia, eu estava tão deslocada e minha mãe tinha todos esses amigos esquisitos que também adoravam cachorros. Ou seja, minha mãe era peculiar. Alguns de seus amigos eram mais da classe trabalhadora, outros mais da classe alta. O mundo canino é muito interessante, vários/as dos/as criadores/as de cães são da classe trabalhadora. Enfim, estou ansiosa por voltar a competir no agility. Alguns dos obstáculos são mais difíceis que os outros e tento trabalhar com meu cachorro três ou quatro vezes por dia nos mais difíceis. Mas agora não estou podendo porque estou falando com você, seu jovem charmoso! [Risos].

CEH: Posso dizer o mesmo sobre o seu charme butch, Esther! [Risos].

EN: Mas por que você está interessado em agility, cães e essas coisas?

CEH: Como esta entrevista diz respeito a toda a sua vida e carreira, o agility parece consumir boa parte de suas paixões atuais. O filme documentário que estão fazendo sobre sua vida ${ }^{28}$ e que está em produção, parece levar o agility muito a sério.

EN: Sim. Uma das produtoras e as cineastas virão filmar minha corrida com meu cão. Estou finalmente voltando para o esporte!

CEH: Considerando que você está tão envolvida em todo o mundo do agility e dos cães, você tem acompanhado os debates antropológicos acerca de estudos sobre animais e espécies companheiras? Tem se interessado por esse debate?

\footnotetext{
${ }^{27}$ Agility, em termos muito simples, é um esporte baseado na interação entre um cão e seu/sua condutor/a, cujas regras inicialmente eram inspiradas no hipismo, e que avaliam a realização competitiva de metas e habilidades com grande velocidade e no menor tempo.

${ }_{28}^{28}$ Se trata do documentário cujo título provisório é "Esther Newton Made Me Gay - Documentary" que vem sendo produzido nos últimos anos sobre a vida de Esther Newton. O documentário é dirigido por Jean Carlomusto e produzido por Shanti Avirgan. Seu lançamento estava previsto para o início de 2020, tendo sido postergado, entretanto, devido à pandemia da COVID-19. Mais informações consultar: https://www.facebook.com/EstherNewtonFilm/.
} 
EN: Sim, mas na verdade minha esposa é quem está interessada nisso ${ }^{29}$. Ela é a artista. Ela é uma artista performática e, de fato, fez um livro sobre animais e performance. Então, estou mais a par disso do que com o que está acontecendo na antropologia atual. Eu me correspondo com Donna Haraway e ela também gosta do agility.

CEH: Mesmo? Parece que o agility está se tornando uma tendência entre antropólogas feministas influentes. [Risos]. Enfim, o que você está achando do documentário sobre sua vida? Você está animada para vê-lo finalizado?

EN: Estou muito empolgada com isso. Tem sido ótimo, maravilhoso. Gosto muito dos filmes de Jean Carlomusto já há muito tempo. Acho que ela é muito boa. Tem sido uma coisa divertida. Já tive pessoas gravando entrevistas comigo antes, principalmente sobre o Mother Camp, mas nunca alguém fazendo algo assim sobre a minha vida. Estou muito animada. E sabe do que mais? Você precisa de coisas assim quando se aposenta. Você precisa de coisas para mantê-lo/a estimulado/ a, para continuar. É um projeto totalmente novo, e tem sido bem divertido, de verdade...

CEH: Ótimo, bem, a última pergunta. My Butch Career, além de um belo livro de memórias, também poderia ser lido como um romance butch muito envolvente. [Esther ri]. A leitura foi muito agradável e acredito que quem o ler será seduzida/o pelo charme da escritora, como eu o fui. Você acredita que seu livro mais recente cumpre seu antigo desejo de escrever um romance como você sonhou em Paris?

EN: Sim, sim, e estou muito feliz com isso. Porque o romance não era realmente um bom formato para mim. Por inúmeras razões. Mas esse livro foi uma boa forma para mim. E, na verdade, é tão importante que as pessoas queer contem nossas histórias. Mas elas precisam ser comunicadas de uma forma que as pessoas entendam. Tem que ter uma certa moldura e formato em termos de estilo e sinto que esse formato funcionou muito bem para mim. E eu ficaria feliz com esse resultado, mesmo que eu não tivesse recebido nenhuma resenha, sabe? Quer dizer, eu sempre achei que Mother Camp era um bom trabalho, mas a indiferença foi tão avassaladora na época que eu não conseguia realmente ter nenhum prazer naquilo. Algumas pessoas hoje em dia, às vezes, falam: "Nossa, o estilo de escrita de Mother Camp é horrível, ridículo". O que é mesmo. Mas era tudo o que havia antigamente. Era extremamente difícil encontrar referências para esse trabalho na época. Portanto, ter pessoas hoje em dia dizendo que gostam do meu livro de memórias e agora eu possuir um site pessoal, coisa da qual nunca precisei nem pensei em ter antes. Pessoas entrando em contato comigo de lugares e contextos tão diferentes. Mesmo com minhas capacidades físicas em declínio, o livro abriu novos mundos para mim e me colocou em contato com pessoas muito interessantes, como você. [Risos].

CEH: Muito obrigado, Esther! Tomei mais de duas horas da sua tarde. Foi algo muito generoso e gentil de sua parte aceitar falar tão francamente sobre tudo isso. Espero encontrá-la de novo em breve.

EN: Eu espero também. Obrigada!

\section{Referências}

BARBOSA DA SILVA, José Fábio. "Aspectos Sociológicos do Homossexualismo em São Paulo". Sociologia, v. XXI, n. 4, p. 350-360, 1959.

BUTLER, Judith. Problemas de Gênero: feminismo e subversão da identidade. Trad. de Renato Aguiar. Rio de Janeiro: Civilização Brasileira, 2003 [1990].

HENNING, Carlos Eduardo. "A dor, a glória e o charme butch de Esther Newton". Revista Estudos Feministas. Florianópolis, v. 27, n. 2, e65259, 2019a. Disponível em https://www.scielo.br/pdf/ref/ v27n2/1806-9584-ref-27-02-e65259.pdf. Acesso em 02/03/2020.

HENNING, Carlos Eduardo. "Leyendo las memorias de Esther Newton: una antropóloga pionera y 'camionera'. Reseña del libro My butch career: A memoir (2018)". Etcétera, Revista del Área de Ciencias Sociales del CIFFYH, n. 4, p. 1-11, 2019b. Disponível em https://revistas.unc.edu.ar/ index.php/etcetera/article/view/25050. Acesso em 02/03/2020.

LAMPHERE, Louise. "Personal reflections on the career of a squeaky wheel". Voices. v. 9, n. 1, p. 09-12, 2009. [Publicado pela primeira vez em: 23/02/2010]. Disponível em https:// anthrosource.onlinelibrary.wiley.com/doi/10.1111/j.1548-7423.2009.tb00036.x. Acesso em 02/03/2020.

NEWTON, Esther. Mother Camp: Female Impersonators in America. Chicago: University of Chicago Press, 1979 [1972].

${ }^{29}$ A artista lésbica e feminista de performance Holly Hughes. 
NEWTON, Esther. "The Mythic Mannish Lesbian: Radclyffe Hall and the New Woman". Signs: Journal of Women in Culture and Society. v. 9, n. 4, p. 557-75, Summer, 1984.

NEWTON, Esther. Cherry Grove, Fire Island: Sixty Years in America's First Gay and Lesbian Town. Durham, NC: Duke University Press, 1993.

NEWTON, Esther. “Dick(less) Tracy' and the Homecoming Queen: Lesbian Power and Representation in Gay Male Cherry Grove". LEWIN, Ellen (ed). Inventing Lesbian Cultures in America, Boston: Beacon Press, 1996. p. 162-193.

NEWTON, Esther. Margaret Mead Made Me Gay: Personal Essays, Public Ideas. Durham, NC: Duke University Press, 2000.

NEWTON, Esther; WALTON, Shirley. Womenfriends: A Soap Opera. New York: Friends Press, 1976.

RUBIN, Gayle. "The Traffic in Women: Notes on the 'political economy' of Sex”. REITER, Rayna (Ed.). Toward an Anthropology of Women. New York: Monthly Review Press, 1975, p. 157-210.

RUBIN, Gayle. "Thinking Sex: notes for a radical theory of the politics of sexuality". VANCE, Carole (ed.). Pleasure and Danger. New York: Routledge and Kegan Paul, 1984, p. 267-319.

RUBIN, Gayle. "Esther Newton Made Me a Gay Anthropologist”. American Anthropologist. v. 120, n. 4, p. 852-853, dez. 2018a.

RUBIN, Gayle. "Estudando Subculturas Sexuais: Escavando as etnografias das comunidades gays em contextos urbanos da América do Norte". Teoria e Cultura, v. 13, n. 1, p. 247-288, 2018b. Disponível em https://periodicos.ufj.br/index.php/TeoriaeCultura/article/view/12413. [Trad. de Carlos E. Henning e Glauco B. Ferreira]. Acesso em 02/03/2020.

RUBIN, Gayle. "Geologias dos estudos queer: um déjà vu mais uma vez". Sociedade e Cultura, Goiânia, v. 19, n. 2, p. 117-125, jul./dez, 2016. Disponível em https://www.revistas.ufg.br/fcs/article/ view/48676. [Trad. de Paula N. P. Batista e Roberto M. X. Reis. Rev. da trad. de Carlos E. Henning e Glauco B. Ferreira]. Acesso em 02/03/2020.

VANCE, Carole (ed.). Pleasure and Danger: exploring female sexuality. Boston: Routledge \& Kegan Paul, 1984.

Carlos Eduardo Henning (carloseduardohenning@ufg.br) é professor de Antropologia na Faculdade de Ciências Sociais e no Programa de Pós-Graduação em Antropologia Social da Universidade Federal de Goiás. Pesquisador do Ser-Tão, Núcleo de Ensino, Extensão e Pesquisa em Gênero e Sexualidade e do NEPEV, Núcleo de Ensino, Pesquisa e Extensão em Gênero e Sexualidade. Tem experiência em pesquisas em antropologia urbana, antropologia das relações de gênero e sexualidade, e antropologia do curso da vida e da velhice.

\section{COMO CITAR ESSE ARTIGO DE ACORDO COM AS NORMAS DA REVISTA}

HENNING, Carlos Eduardo. "O Charme Sapatão de Esther Newton: uma entrevista sobre a vida, a obra e as paixões da lendária antropóloga". Revista Estudos Feministas, Florianópolis, v. 28, n. 3, e76427, 2020.

\section{CONTRIBUIÇÃO DE AUTORIA}

Não se aplica.

\section{FINANCIAMENTO}

Não se aplica.

CONSENTIMENTO DE USO DE IMAGEM

Não se aplica.

APROVAÇÃO DE COMITÊ DE ÉTICA EM PESQUISA

Não se aplica. 


\section{CONFLITO DE INTERESSES}

Não se aplica.

LICENÇA DE USO

Este artigo está licenciado sob a Licença Creative Commons CC-BY International. Com essa licença você pode compartilhar, adaptar, criar para qualquer fim, desde que atribua a autoria da obra.

\section{HISTÓRICO}

Recebida em 14/08/2020

Aprovada em 18/08/2020 